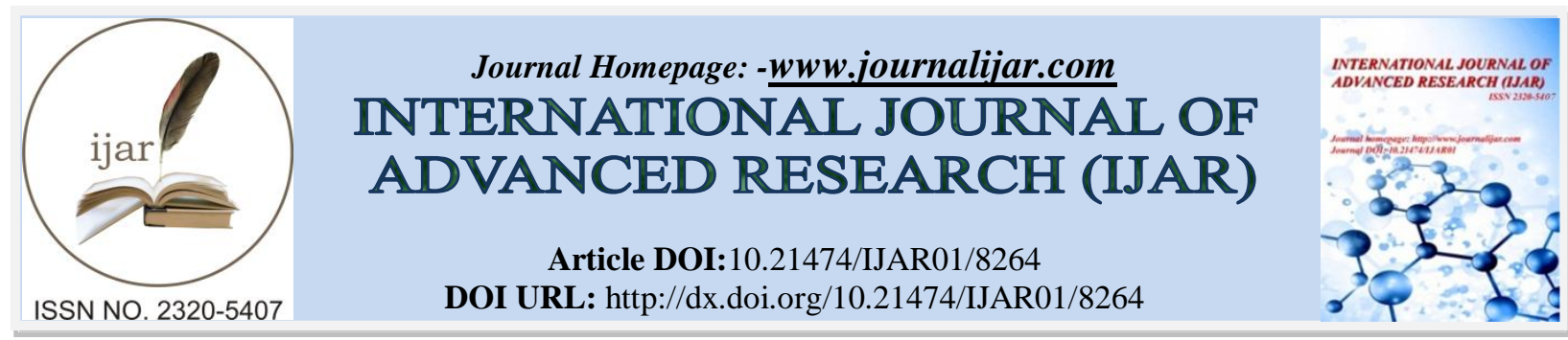

RESEARCH ARTICLE

\title{
ANALYSIS ON BRAND EQUITY OF RJV COLD-PRESSED JUICE.
}

\author{
Annisa Azlina ${ }^{1}$, Hartoyo ${ }^{1}$ and Kirbrandoko ${ }^{2}$. \\ 1. School of Business, Bogor Agricultural University, Indonesia. \\ 2. Departementof Business Management, Bogor Agricultural University, Indonesia.
}

\section{Manuscript Info}

\section{Manuscript History}

Received: 20 October 2018

Final Accepted: 22 November 2018

Published: December 2018

Keywords:-

Marketing, Marketing Mix, Brand

Equity, SEM (Structural Equation Model)

\begin{abstract}
This study aims to analyze brand equity of the RJV cold-pressed juice according to the consumer's perspective through marketing efforts that have been made by the company. The sample collection of the study was carried out using convenience sampling technique. The number of respondents of the study was 250 respondents which were obtained based on the rule of thumb. The independent variables include product, price, outlet and promotion. In addition, the dependent variables include brand equity and brand equity dimensions which consist of brand awareness and association, percieved quality, and brand loyalty. The data processing and analysis techniques of this study apply quantitative descriptive analysis. It used SEM analysis tools with the help of LISREL 8.8 software. The findings showed that product and promotion have positive and significant effect on brand awareness and association. Product, outlet and promotion have positive and significant effect on the percieved quality. Product and price have positive and significant effect on brand loyalty. In addition, there is a positive effect on all dimensions of brand equity towards brand equity; however, only the Percieved quality and brand loyalty that have significant effect. These findings indicated that marketing efforts made by the company will increase and strengthen brand equity in the consumer's perspective.
\end{abstract}

Copy Right, IJAR, 2018,. All rights reserved.

\section{Introduction:-}

Along with the development of science and technology, there are changes in processing food, such as fruits and vegetables, in which it is currently not only consumed directly but can be processed into fruit and vegetable juices. Recently, the industry of cold-pressed juice has sprung up which aims to support the needs of the people who are beginning to change their lifestyle to the healthier one by drinking fruit or vegetable juice but they do not have much time to make it themselves. One of the companies or manufacturers in the cold-pressed juice industry is RJV. RJV is a product brand of PT SSP and is a pioneer in the cold-pressed juice industry in Indonesia. The sales of RJV cold-pressed juice increased by more than $100 \%$ in 2016 . It means that the market share of cold-pressed juice is getting higher. Thus, in 2017, the company opened 16 outlets to increase sales. Up to now, there are 40 outlets spread in Jakarta, Tangerang, Cibubur and Bogor.

There area lot and even increasing juice or fruit juice industry in Indonesia. However, fruit juice products in the market are more to ready-to-drink juice and some still contain preservatives, sugar and even artificial 
sweeteners. According to Fathiyah, Sumarwan, and Tanziha (2005), the number of fruit juice in the market will make consumers more selective in choosing the fruit juice they will consume. Data from the Ministry of Industry (2012) recorded that the growth of fruit juice was 15\% in 2011 and $20 \%$ in 2012.

Due to the increasing growth of the market and industry of juice or fruit juice, cold-pressed juice companies or producers need to carry out the proper marketing strategies and strengthen brand equity to win thecompetition in this industry. According to Aaker (1997), brand equity is a set of assets and liabilities related to its brand, name and symbol that increase or decrease the value given by a product or service to the company or the customers of the company. By understanding the dimensions of brand equity and their level of effect on the company's brand, it allows managers to make appropriate planning in achieving brand goals (Gholami, Roushanghias, and Karimiankakolak, 2016). Yoo, Donthu, and Lee (2000) mentioned that besides being formed by the dimensions of brand equity such as brand awareness, brand association, Percieved quality and brand loyalty, brand equity is also formed by marketing efforts. Marketing efforts that can be carried out is the formulation of dimensions in the marketing mix which consists of product, price, place, and promotion (4P). In addition, marketing efforts made by companies can increase or even reduce brand equity. Marketers must know what factor contributes the most to brand equity from the marketing mix elements and brand equity dimensions of the product being marketed. Moreover, it will produce the strategies that can be taken to build strong brand equity (Rahmawati 2013). The study aims to analyze the contribution of marketing efforts and the dimensions of brand equity to the formation of RJV brand equity.

This research was conducted to find out the correlation and contribution of the marketing mix and the dimensions of brand equity to the formation of brand equity. The brand equity model of RJV cold-pressed juice (Figure 2. Conceptual Thinking Framework) is formed from four exogenous latent variables which include product, price, outlet, and promotion variables, as well as four endogenous variants that include latent mediation variable namely brand awareness and association, brand impression, brand loyalty, and brand equity variables. Based on the conceptual framework, the following are the hypotheses that will be tested in this study:

H1: Brand awareness and association have positive correlation with brand equity

$\mathrm{H} 2$ : Percieved quality has positive correlation with brand equity

H3: Brand loyalty has positive correlation with brand equity

H4: Product has positive correlation with brand awareness and association

H5: Promotion has positive correlation with brand awareness and association

H6: Product has positive correlation with the Percieved quality

H7: Price has positive correlation with the Percieved quality

H8: Outlet has positive correlation with the Percieved quality

H9: Promotion has positive correlation with the Percieved quality

H10: Product has positive correlation with brand loyalty

H11: Price has positive correlation with brand loyalty

\section{Research Method:-}

\section{Research Setting and Period:-}

This research was conducted in July 2017 to January 2018 in the Jakarta, Tangerang and Bogor regions. The research setting was chosen deliberately under the consideration of the ease in obtaining the respondents and the setting of the RJV outlets.

\section{Research Design:-}

This study applies quantitative and qualitative research designs. Quantitative research design is used to analyze data from interviews and questionnaires on the research objects and respondents. Meanwhile, the qualitative research design is used to analyze questionnaire data which produces scores that will be processed statistically through the SPSS for Windows program.

\section{Data Collection Technique:-}

The research data include primary and secondary data. Primary data were obtained from interviews and questionnaires, that have been tested for their reliability, to a number of respondents. Meanwhile, secondary data were obtained from various sources both internal and external aspects of the company, literature and previous research. 


\section{$\underline{\underline{1276}}$}

\section{Sampling Technique:-}

In this study, the sampling technique used non-probability sampling by applying convenience sampling; i.e. selection of population elements where each member has no chance of being selected. Through this convenience sampling method, members of the population are taken on the basis of convenience where respondents are visitors to RJV outlets. For instance, the criteria for prospective respondents in this survey were consumers who had visited RJV outlets, bought and consumed RJV for the past year and were aged $\geq 17$ years. The number of respondents was taken using a rule of thumb from structural equation modeling (SEM). According to Hair et al (2006), the number of samples needed for each estimated parameter of the exogenous and endogenous variables is five to ten observations. Since the number of indicator variables that make up the SEM model of this study are 38 arrows, if each variable takes five to ten observations, then the number limit for the sample is between $38 \times 5=190$ people to $38 \times 10=380$ people. Respondents taken were 250 respondents, with consideration that there will be invalid respondent data, so that the respondents were no less than the minimum limit.

\section{Variable Measurement:-}

This study uses four exogenous variables which are marketing mix dimensions and four endogenous variables which are brand equity and its dimensions. The marketing mix variables examined in this study are product variant, price, outlet, and promotion. In addition, the brand equity dimensions analyzed in this study are brand awareness which is combined with brand association, Percieved quality, and brand loyalty (Table 1). These variables are measured using a Likert scale (scale 1-5). Number 1 indicates strongly disagree and number 5 indicates strongly agree.

Table 1 Research Variables

\begin{tabular}{|c|c|c|c|}
\hline $\begin{array}{l}\text { Elements / } \\
\text { Dimensions }\end{array}$ & Variables & $\begin{array}{c}\text { Indicator } \\
\text { Codes }\end{array}$ & Indicators \\
\hline \multirow{12}{*}{$\begin{array}{l}\text { Marketing Mix } \\
\text { (X) }\end{array}$} & \multirow[t]{3}{*}{ Product } & PD1 & RJV products have a lot of variety \\
\hline & & PD2 & RJV juice tastes delicious \\
\hline & & PD3 & $\begin{array}{l}\text { RJV products are different from competitor's } \\
\text { products }\end{array}$ \\
\hline & \multirow[t]{3}{*}{ Price } & PC1 & RJV price matches the quality \\
\hline & & $\mathrm{PC} 2$ & RJV price reflects a premium brand \\
\hline & & PC3 & RJV price reflects high quality \\
\hline & \multirow[t]{3}{*}{ Outlet } & OT1 & Outlet location reflects a premium brand \\
\hline & & OT2 & Outlet reflects a premium brand \\
\hline & & OT3 & Outlet reflects a high-quality image \\
\hline & Promotion & PM1 & Interested in RJV bundle promotion \\
\hline & & PM2 & Interested in buy-two-get-one-free promotion \\
\hline & & PM3 & $\begin{array}{l}\text { Interested in promotional discounts using credit } \\
\text { cards }\end{array}$ \\
\hline \multirow[t]{10}{*}{$\begin{array}{l}\text { Brand Equity } \\
(\mathrm{Y})\end{array}$} & \multirow{6}{*}{$\begin{array}{c}\text { Brand } \\
\text { Awareness and } \\
\text { Association }\end{array}$} & AA1 & Familiar with RJV cold-pressed juice \\
\hline & & AA2 & Remember the RJV logo quickly \\
\hline & & AA3 & Be able to distinguish RJV from other brands \\
\hline & & AA4 & RJV is a brand of premium cold-pressed juice \\
\hline & & AA5 & RJV is a brand of fresh fruit juice \\
\hline & & AA6 & $\begin{array}{l}\text { RJV is a brand of natural cold-pressed fruit and } \\
\text { vegetable juices without added sugar and } \\
\text { preservatives }\end{array}$ \\
\hline & $\begin{array}{l}\text { Percieved } \\
\text { quality }\end{array}$ & IQ1 & RJV brand products have high quality \\
\hline & & IQ2 & RJV brand product quality is hygienic \\
\hline & & IQ3 & RJV brand juice products are always fresh \\
\hline & Brand Loyalty & BL1 & Keep choosing RJV even though there are other \\
\hline
\end{tabular}




\begin{tabular}{|l|l|l|l|}
\hline & & & brands of the same quality \\
\hline & & BL2 & $\begin{array}{l}\text { Keep choosing RJV even though there are other } \\
\text { brands at lower prices }\end{array}$ \\
\hline & Brand Equity & BE1 & RJV will be the first choice \\
\hline & & BE2 & RJV is a brand of premium cold-pressed juice \\
\hline & & BE3 & RJV is the best brand of cold-pressed juice \\
\hline
\end{tabular}

Data Processing and Analysis Technique.This study applies Structural Equation Modeling method, which is a statistical tool capable of analyzing latent variables, indicator variables, and measurement errors directly (Sitinjak and Sugiarto, 2006). This study adopts brand equity research conducted by Yoo, Donthu, and Lee (2000) which found that besides being formed by the dimensions of brand equity such as brand awareness and association, the Percieved quality, and brand loyalty, brand equity is also formed by marketing efforts.

\section{Result And Discussion:-}

Respondent Characteristics:-

The research samples were RJV consumers who had visited RJV outlets, bought and consumed RJV for the past year and were $\geq 17$ years old. The following are the results of the most dominant demographic characteristics in this study as presented in Table 2 .

Table 2:-Respondent Demographic Characteristics

\begin{tabular}{|l|l|c|c|}
\hline \multicolumn{1}{|c|}{ Sample Characteristics } & \multicolumn{1}{|c|}{ Categories } & Total (n) & Percentage (\%) \\
\hline Gender & Female & 157 & 62.8 \\
\hline Age group & 23-28 years & 144 & 57.6 \\
\hline Educational background & Bachelor & 187 & 58.5 \\
\hline Occupation & Private employee & 143 & 57.2 \\
\hline Income per month & IDR 5,000,000 - IDR 10,000,000 & 89 & 35.6 \\
\hline
\end{tabular}

\section{Consumption Behavior:-}

Based on the research findings, it was found that the respondents' reasons for consuming cold-pressed juice were dominated by the reason for vitamin content benefits with a percentage of $57.6 \%$, while healthy lifestyle was the most reason of the respondents in consuming RJV cold-pressed juice with a percentage of $44 \%$. Then, the research findings showed that more than 186 of the 250 respondents did not consume cold-pressed juice other than RJV brand and $79.5 \%$ of those who did not consume cold-pressed juice of other brands were respondents who did not know cold-pressed juice other than RJV brand. Naked Cold-Pressed Juicery is a brand of cold-pressed juice other than RJV that dominates consumer knowledge about cold-pressed juice. There were 41 respondents who knew the brand and 25 of them consumed that cold-pressed juice brand. The respondents of this study were dominated by consumers who had just consumed the RJV brand of cold-pressed juice for less than 3 months, which was $39.2 \%$. Overall, more than $60 \%$ of respondents have consumed RJV brand of coldpressed juice for more than 3 months. The frequency of consumption in this study was dominated by respondents who consumed 1-2 bottles of RJV cold-pressed juice every week by $56 \%$.

RJV brand of cold-pressed juice is easily found and got because RJV has 40 outlets spread in Jakarta, Tangerang and Bogor cities. Based on the research findings, it was known that the majority of respondents in this study often make purchases at outlets in Jakarta City; as many as more than $74 \%$ of respondents. This study showed that the amount of money sacrificed by respondents to buy and consume RJV brand of cold-pressed juice every month ranges from IDR 100,000 - IDR 500,000. The majority of respondents with a percentage of $66 \%$ still use cash as a method of payment when purchasing the products.

\section{Effect of Indicators on Latent Variables:-}

There are 8 latent variables discussed in this study consisting of product, price, outlet, promotion, brand awareness and association, Percieved quality, brand loyalty, and brand equity. Latent variables cannot be directly observed or measured. Latent variables are measured by one or more indicator variables (Hair et al 2010). Every latent variable in this study was formed by more than 1 indicator. Therefore, to find out the effect of each indicator on its latent variables, the calculation of the t-test was carried out on each indicator with the 
standard error of 5\% and t-table of 1.96. In addition, to find out the correlation between the indicator and the latent construct, a loading factor calculation was performed. Indicators with high loading factor values have a higher contribution to explain the latent construct. According to Hair et al (2010), the amount of loading factor of $>0.50$ is considered to have strong enough validation to explain the latent construct. The results of data processing using SEM modeling can be seen in the following Figure 3 for the loading factor value.

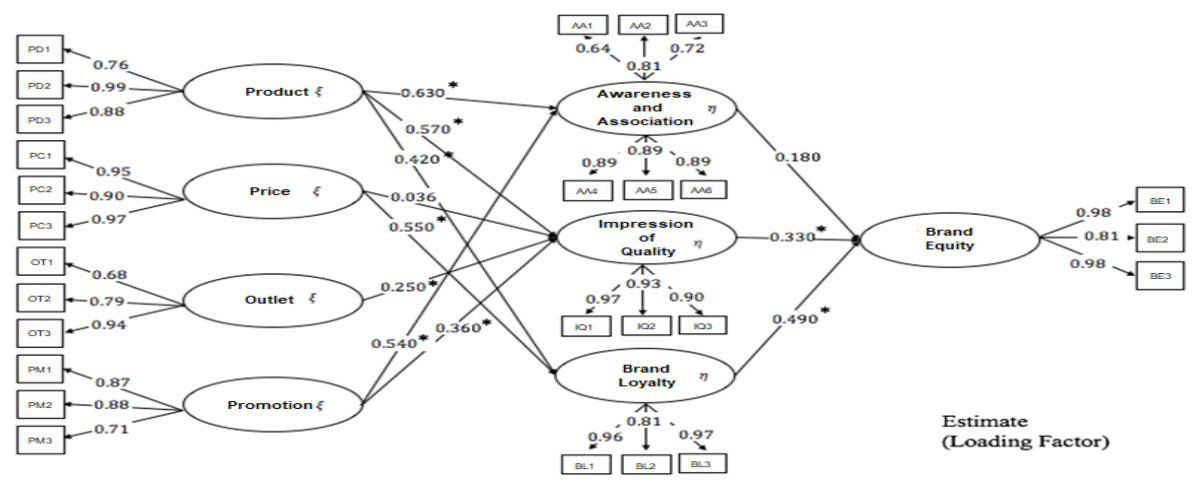

Description:-loading factor values of $>1.96$ mean significant effect

Figure 3:-Standardized Loading Factors

Table 3:-the Results of Goodness of Fit

\begin{tabular}{|c|c|c|c|}
\hline Goodness of Fit & CutoffValue & Results & Description \\
\hline RMSEA & $\leq 0.08$ & 0.030 & Good Fit \\
\hline GFI & $>0.90$ & 0.99 & Good Fit \\
\hline AGFI & $>0.90$ & 0.99 & Good Fit \\
\hline IFI & $>0.90$ & 1.01 & Good Fit \\
\hline NFI & $>0.90$ & 1.00 & Good Fit \\
\hline
\end{tabular}

\section{Results of Measurement Model Fit:-}

The measurement model fit was carried out through reliability test. To test the reliability of the data, this study uses indicators based on the Variance Extracted (VE) and Construct Reliability (CR) formula. The results of the measurement model fit are presented in the following Table 4.

Table 4:-Results of Measurement Model Fit

\begin{tabular}{|l|c|c|c|}
\hline \multicolumn{1}{|c|}{ Latent Variables } & $\mathrm{CR} \geq 0.70$ & $\mathrm{VE} \geq 0.5$ & Description \\
\hline Product & 0.90 & 0.75 & Valid \\
\hline Price & 0.98 & 0.93 & Valid \\
\hline Outlet & 0.85 & 0.66 & Valid \\
\hline Promotion & 0.86 & 0.68 & Valid \\
\hline Awareness and Association & 0.92 & 0.66 & Valid \\
Percieved quality & 0.95 & 0.87 & Valid \\
Brand Loyalty & 0.93 & 0.82 & Valid \\
Brand Equity & 0.94 & 0.84 & Valid \\
\hline
\end{tabular}

VE values are used to measure the number of variants that can be captured by the construct compared to the variance caused by measurement errors. Meanwhile, the composite reliability values show the consistency of each indicator in measuring the construct. The higher the composite reliability value, the more consistent the indicator is in measuring the construct. Ghozali (2013) explained that indicators of variables are reliable if the AVE value is $\geq 0.05$ and $C R \geq 0.07$. The results of processing in Table 20 show that all construct reliability values and variance extracted in this study are above 0.70 and 0.50 . so, it is concluded that the models of this study are reliable to use. 


\section{Results of Hypothesis Testing:-}

The results of hypothesis testing showed that there are two hypotheses with insignificant results, namely hypothesis 1 (brand awareness and association have positive correlation with brand equity) and hypothesis 7 (price has positive correlation with the Percieved quality) as shown in Table 5. The dimensions of brand loyalty are the most dominant dimension in forming RJV brand equity compared to other dimensions; with loading factor value of 0.49 . Then, the product becomes the marketing mix dimension which has the greatest positive correlation to the two dimensions of brand equity, namely the dimensions of brand awareness and association and Percieved quality. For brand loyalty, the marketing mix dimension that contributes most is the price dimension with loading factor value of 0.55 .

Table 5:-Results of SEM Model Estimation

\begin{tabular}{|l|c|c|c|}
\hline \multicolumn{1}{|c|}{ Hypotheses } & Loading Factors & $\begin{array}{c}\mid \text { t-cal| }> \\
1.96\end{array}$ & Description \\
\hline $\begin{array}{l}\text { H1: Brand awareness and association have positive } \\
\text { correlation with brand equity }\end{array}$ & 0.180 & 1.14 & Not significant \\
\hline $\begin{array}{l}\text { H2: Percieved quality has positive correlation with brand } \\
\text { equity }\end{array}$ & 0.330 & 2.73 & Significant \\
\hline H3: Brand loyalty has positive correlation with brand equity & 0.490 & 6.16 & Significant \\
\hline $\begin{array}{l}\text { H4: Product has positive correlation with brand awareness } \\
\text { and association }\end{array}$ & 0.630 & 34.17 & Significant \\
\hline $\begin{array}{l}\text { H5: Promotion has positive correlation with brand } \\
\text { awareness and association }\end{array}$ & 0.540 & 32.65 & Significant \\
\hline $\begin{array}{l}\text { H6: Product has positive correlation with the Percieved } \\
\text { quality }\end{array}$ & 0.570 & 10.15 & Significant \\
\hline $\begin{array}{l}\text { H7: Price has positive correlation with the Percieved quality } \\
\text { Hypotheses }\end{array}$ & 0.036 & 0.41 & Not significant \\
\hline $\begin{array}{l}\text { H9: Promotion has positive correlation with the Percieved } \\
\text { quality }\end{array}$ & 0.360 & 5.40 & Significant \\
\hline H10: Product has positive correlation with brand loyalty & 0.420 & 13.09 & Significant \\
\hline H11: Price has positive correlation with brand loyalty & 0.550 & 18.02 & Significant \\
\hline
\end{tabular}

Description:-t-calculatevalue > t-table 1.96 means significant

\section{Managerial Implications:-}

The research findings showed that the majority of RJV's cold-pressed juice consumers are those who pay attention to health. It is reflected from their reasons in consuming RJV cold-pressed juice which contains benefits from the content of vitamins and a healthy lifestyle. RJV's consumersare dominated by new consumers with the frequency of consuming 1-2 bottles per week. It means that the company needs to make more efforts so that new consumers are interested in buying and consuming RJV cold-pressed juice more; for instance, conducting promotions which can convince the consumers by emphasizing the advantages and benefits of products by having regular consumption. Consumers with a high frequency of purchases and consumption of cold-pressed juice are old consumers of RJV. There are only a small number of old consumers in this study who still consume RJV cold-pressed juice in small amounts. This should become the main concern to the company. Companies can follow up on old consumers who still consume RJV cold-pressed juice in small amounts and find out why these consumers only consume RJV cold-pressed juice 1-2 bottles per week so that an evaluation can be conducted. Moreover, the company can also solve approachthe old consumers, who used to consume RJV cold-pressed juice in high frequency of consumption, by offering a delivery service every week. The company certainly needs to create a better consumer database to more effectively support these efforts.

Based on the research findings, the brand equity that gives the greatest contribution to the formation of RJV brand equity is the brand loyalty through price. Consumers who are not loyal have a percentage of less than $30 \%$. Based on the respondent characteristics, the majority of consumers have a high enough income and choose to consume RJVdue to the high-quality taste and long duration of RJV cold-pressed juice consumption. It means that these consumers are actually loyal consumers because they have not found other brands of products that 


\section{$\underline{\underline{1276}}$}

have the same characteristics and quality even though there are other brands that offer lower prices. In addition, high prices are not a factor that affects consumers to be disloyal and move to other brands.Consumers are willing to pay more because most of the consumers feel that RJV product's price is in accordance with the quality it provides. Helsen and Schmittlein in Yoo, Donthu, and Lee (2000) stated that although prices are generally an evaluation criterion for consumers in evaluating a product but price is not a consideration to determine loyal and disloyal consumers. Loyal consumers are generally willing to pay in full or more because they prefer high-quality brand. They also have low price sensitivity compared to non-loyal consumers. Thus, it is concluded that RJV has the potential to create loyal consumers by utilizing its superiority compared to other brands.

RJV products have not been registered with the Food and Drug Supervisory Agency (BPOM) and do not have halal certification. It would be better if the company registers its products to BPOM and submits a letter or halal certificate from Indonesian Ulema Council (MUI) so that the company can include halal labels and marketing permit numbers on product packaging. That needs to be carried out as an effort in creating and maintaining brand loyalty by treating consumers appropriately. In addition, it also aims to fulfill company obligations and the right of consumers to obtain the best quality products. It is not only to gain consumer trust but also guarantee the quality of products given to consumers in order to increase consumer loyalty.

The company can continue to carry out programs that have been undertaken to improve close relationships with customers; for instance, Juice Talk Friday or holding other interesting and positive events related to a healthy lifestyle. In addition, the company also needs to improve services to be more responsive to hot line and social media for complaints and delivery services as well as continue to do excellent service to consumers in outlets. In addition, the company can also give congratulatory cards to customers who are loyal at certain moments so that consumers feel happy about the appreciation which finally will lead to emotional bonds or good relationships with consumers. Management of customer satisfaction also needs to be conducted by measuring customer satisfaction; for instance, periodically distributing customer satisfaction surveys, receiving criticism and suggestions, and conducting direct interviews. Thus, companies can evaluate and improve their products and services to meet customer expectations and improve their satisfaction.

RJV can create and utilize transition costs by building the competitive advantage that it already has. For example, one large bottle of RJV cold-pressed juice contains one kilogram of fruit and vegetables without added sugar and preservatives. In addition to keeping customers from moving to other brands, the strategy of winning market competition by utilizing the transition costs is also intended to create strategic thinking, innovate and see potential in the future. Then, the company can also provide rewards for customer loyalty and make extra gifts in order to increase customer loyalty such as giving food bonuses for every purchase of at least a few bottles in one transaction, or bonus of beverage cooler bags after several purchases.

The strategy to build and enhance the impression of consumer quality on products is to continue to develop or innovate products and commit to product quality by maintaining it continuously. The company also needs to win product quality above other aspects. In addition, research on consumers about product quality also needs to be conducted so that the company knows consumer expectations about it. Then, the product must also have clear quality standards. Finally, the company must involve employees in controlling the quality of services at the outlets.

The quality factors that RJV can also consider are taste, freshness, product durability, and product benefits. Companies need to maintain and even enhance the product's taste image, as well as provide a more varied choice of flavors to consumers while maintaining its high taste. In addition, maintaining the freshness of raw materials and freshness of the product is also important, considering that the product is cold-pressed juice which is believed to have high vitamin content because its manufacturing does not through heating process. Product durability also needs to be considered even though RJV does not add preservatives to its products. Moreover, the company needs to pay attention to the productson the display whether or not they are nearing their expired date. Therefore, it prevents consumers from receivingnon-consumable products. This can be overcome by adjusting the amount of production with the average number of sales per day so that there are no products left. The company needs to consider and inform the benefits of the products in order to provide the consumers the impression of good quality. If the impression of product quality is good at the consumer's perspective, it can be a reason to buy more. Product differentiation with other brand products at the consumer's perspective can set 
premium prices which of course will add the company's profits. In addition, a strong quality impression can be made for brand expansion so that it is possible to gain a greater market share. Impression of positive quality at the consumer's perspective will certainly increase and strengthen brand equity so that it will generate consumer trust that will make the brand stronger. It is only be able to make old consumers keep consuming RJV coldpressed juice product and not moving to other brand products, but it will also attract new consumers.

In this study, promotion also contributes positively to the impression of the quality of RJV. Therefore, the company needs to pay attention to promotion in order to increase the impression of the quality of the RJV brand which will lead to strengthening brand equity. The company need to make various promotional efforts in other forms that reflect the impression of good quality, such as making creative promotions or marketing on digital and social media; for example, making more interesting and neat Instagram content, collaborating withinfluencers who have good reputation toendorse RJV products, or holding various events like workshops on healthy lifestyles.

\section{Conclusions:-}

RJV consumers in this study were dominated by women, age group of 23-28 years, undergraduate education, private employees, and income of $\geq$ IDR 3,500,000. Product and promotion have positive and significant effect on brand awareness and association. All dimensions of the marketing mix (product, price, store, and promotion) contribute positively to the Percieved quality, but price has no significant effect. Product and price have positive and significant contribution to brand loyalty. All dimensions of brand equity positively have effect on brand equity. However, it is only the Percieved quality and brand loyalty that have significant effect. The dimension of brand equity that has the highest effect on the formation of RJV brand equity is brand loyalty dimension.

Brand loyalty is a brand equity dimension that contributes the most in forming and strengthening brand equity. The company can focus on building and maximizing RJV brand loyalty. With proper management and utilization, brand loyalty can be a strategic asset for the company. Thus, the effort that can be made to create and maintain brand loyalty is to treat consumers appropriately such as registering their products with Food and Drug Supervisory Agency (BPOM) and making halal certification, establishing close relationships with customers by organizing events involving customers such as workshops on healthy living and doing responsive and prime service, and giving congratulatory cards to loyal customers at certain moments so that consumers feel happy about the appreciation which finally will lead to emotional bonds or good relationships with consumers. The company also needs to manage customer satisfaction by measuring customer satisfaction through periodic customer satisfaction surveys. RJV can create and utilize transition costs by strengthening the competitive advantages it has.Then, the company can also provide rewards for customer loyalty and make extra gifts in order to increase customer loyalty such as giving food bonuses for every purchase of at least a few bottles in one transaction, or bonus of beverage cooler bags after several purchases.

\section{References:-}

1. Aaker DA. 1997. Brand Management: Utilizing The Value of Brand. TranslatedbyArisAnanda. Jakarta: Spektrum.

2. Fathiyah, Sumarwan U, Tanziha I. 2005. Analysis of Knowlege of Nutrition beverage products (juice) consumed by IPB Students. Nutrition and Family Media Journal.

3. Ghozali I. 2013. Aplication of Multivariate Analysis with The SPSS Program. Semarang: DiponegoroUniversity Publisher.

4. Ministry of Industry Indonesia. 2012. Trend and Growth Prospect of Drink Industry in 2012. Jakarta: DirektoratGeneral of AgroIndustry.

5. Rahmawati M. 2013. Brand Equity Analysis of Minute Maid Juice in Bogor. [Thesis]. Bogor (ID): Bogor Agricurtural University.

6. Sitinjak JRT, Sugiarto. 2006. LISREL. Yogyakarta: GrahaIlmu.

7. Yoo B, Donthu N, Lee S. 2000. An examination of selected marketing mix elements and brand equity. Journal of the Academy of Marketing Science. 28(2): 195-211. 